\title{
Environmental, Behavioral Factors and Filariasis Incidence in Bintan District, Riau Islands Province
}

\author{
Faktor Lingkungan, Perilaku, dan Kejadian Filariasis di Kabupaten Bintan, \\ Kepulauan Riau
}

Zainul Ikhwan*, Lucky Herawati**, Suharti***

*Environmental Health Study Program, Health Polytechnic of Tanjungpinang, Tanjungpinang, Indonesia, **Environmental Health Department, Health Polytechnic of Yogyakarta, Yogyakarta, Indonesia, ***Nursing Studies, Health Polytechnic of Tanjungpinang, Tanjungpinang, Indonesia

\begin{abstract}
Microfilaria rate of filariasis in Bintan District remains high, especially in Teluk Bintan, Teluk Sebong, and Sri Kuala Lobam Subdistricts. This study aimed to determine relation between environmental risk factors (physical, biological, chemical, socio-cultural, economic) and behavioral factors with filariasis incidence. The study was an analytic observational study conducted on May - September 2015 using case control design, which consisted of a total of case as many as 33 filariasis sufferers and a total of control as many as 65 non filariasis sufferers as taken by cluster sampling technique. Population of study was people in Bintan District. Data obtained were then analyzed by using chi square and logistic regression test. Results showed correlation of knowledge $(p$ value $=0.045$; $O R=1.365)$, wire-net use ( $p$ value $=0.048 ; O R=1.381)$, stockyard ( $p$ value $=0.018 ; O R=3.5)$, swamp $(p$ value $=0.038 ; O R=1.358)$, plantation/forest $(p=$ 0.035 ; $O R=0.373$ ) and mosquito-net use ( $p$ value $=0.036 ; O R=1.417$ ) as risk factor of filariasis incidence. In conclusion, variables most related to filariasis incidence in Bintan District are knowledge $(\mathrm{OR}=6.154)$, mosquito-net use $(\mathrm{OR}=3.861)$ and distance to swamp $(\mathrm{OR}=3.668)$.
\end{abstract}

Keywords: Behavior, environment, filariasis, risk factors

\section{Abstrak}

Tingkat mikrofilaria filariasis di Kabupaten Bintan masih tinggi, khususnya di Kecamatan Teluk Bintan, Teluk Sebong, dan Sri Kuala Lobam. Penelitian ini bertujuan untuk mengetahui hubungan faktor risiko lingkungan (faktor fisik, biologi, kimia, sosial budaya, ekonomi) dan faktor perilaku dengan kejadian filariasis. Jenis penelitian observasional analitik yang dilakukan pada Mei - September 2015 dengan desain kasus kontrol, yang terdiri dari jumlah kasus 33 orang penderita filariasis dan kontrol 65 orang bukan penderita filariasis dengan teknik cluster sampling. Populasi penelitian adalah masyarakat di Kabupaten Bintan. Data yang diperoleh dianalisis menggunakan uji kai kuadrat dan regresi logistik. Hasil menunjukkan adanya hubungan pengetahuan (nilai $p=0.045 ; 0 R=$ 1.365), kawat kasa (nilai $p=0.048$; $O R=1.381$ ), kandang ternak (nilai $p=0.018 ; O R=3,5$ ), rawa-rawa (nilai $p=0.038 ; O R=1.358$ ), perkebunan/hutan (nilai $p=0.035 ; O R=0.373$ ), dan penggunaan kelambu (nilai $p=0.036$; $O R=1.417$ ) sebagai faktor risiko kejadian filariasis. Sebagai kesimpulan, variabel yang paling berhubungan dengan kejadian filariasis di Kabupaten Bintan adalah pengetahuan $(\mathrm{OR}=6.154)$, penggunaan kelambu $(\mathrm{OR}=3.861)$ dan jarak dengan rawa-rawa $(\mathrm{OR}=3.668)$.

Kata kunci: Perilaku, lingkungan, filariasis, faktor risiko

How to Cite: Ikhwan Z, Herawati L, Suharti. Enviromental, behavioral and filariasis incidence in Bintan District, Riau Island Province. Kesmas: National Public Health Journal. 2016; 11 (1): 39-45. (doi:10.21109/kesmas.v11i1. 546)
Correspondence: Zainul Ikhwan, Environmental Health Study Program, Health Polytechnic of Tanjungpinang, Anggrek street No. 3 Bukit Cermin Subdistrict, West Tanjungpinang, Tanjungpinang 29124, e-mail: zainul.ikhwan@gmail.com Received: January $20^{\text {th }} 2016$

Revised: May $15^{\text {th }} 2016$

Accepted: June $16^{\text {th }} 2016$ 


\section{Introduction}

Filariasis known as elephantiasis, up to now still becomes one of public health problems in the world, especially in Indonesia. In 2004, filariasis infected 120 million people in 83 countries, mainly in tropical and sub-tropical regions. It is estimated that one fifth of world's inhabitants or about 1.1 billion people are at risk of getting filariasis infection. ${ }^{1}$ The rapid survey of filariasis in 2000 reported that this disease has spreaded to all provinces in Indonesia consisting of 231 regencies, 674 community health centers, and 1,533 villages, with the number of chronic clinical cases (elephantiasis) around 6,500 people. Meanwhile, in 2004, the number of clinical cases both in the form of acute and chronic filariasis increased to $11,969.2$

The case of clinical filariasis is that sufferers of Filaria worm infection show the clinical symptoms that attack lymph duct and lymph gland, damage lymphatic system, and the manifestation of swollen hands, legs, glandula mamae and scrotum. Differ from Malaria and hemorrhagic fever, filariasis can be infected by 23 mosquito species from the genus of Anopheles, Culex, Mansonia, Aedes, and Armigeres. Therefore, this disease can circulate very rapidly. ${ }^{3}$ The results of a study conducted by Ramadhani, ${ }^{4}$ showed a high of microfilaria number and morbidity rate of acute filaria $(0.4 \%)$, as well as the high density of microfilaria parasite of Wuchereria bancrofty as one of filariasis agents. This disease may lead to permanent physical defect, social stigma, and psychosocial barrier as well as the decrease of work productivities of individual, family and the community, so that leads to huge economic lost. 5

Filariasis is triggered by the condition of physical environment encompassing climate, geographical situation, geological structure, etc. Physical environment factors highly relate with breeding and resting places of the mosquito vectors. The environment of breeding places (swamp) with water plants and the existence of reservoir host animals (such as monkey, langur and cat) intensely affect the spread of filariasis by Brugia malayi of both sub-periodic nocturna and non-nocturna types. ${ }^{5} \mathrm{~A}$ publication of Srividya, et al, 6 titled "A Geostatistical Analysis of the Geographic Distribution of Lymphatic Filariasis Prevalence in Southern India” yielded a prevalence disparity between filariasis cases among people living in mountain and coastal areas.

Bintan District, Batam City and Lingga District are filariasis-endemic areas in Riau Islands Province. ${ }^{7}$ A finger blood survey was held in Tembeling Village and Bintan Buyu Village in 2012 in which the blood samples were examined in the laboratory of Environmental Health Technique (Balai Teknik Kesehatan Lingkungan/BTKL) of Batam. The examination found 53 microfilaria positive blood samples, for instance, 28 out of 318 samples in
Tembeling Village $(8.8 \%)$ and 25 out of 343 samples in Bintan Buyu Village (7.3\%). Microfilaria rate in Bintan District by $8 \%$ meant that the district is categorized as filariasis-endemic area that should follow the eliminating program. Mass medication is conducted once a year for a period of five years. It aims to reduce the prevalence of microfilaria to less than $1 \%$, and to improve the management of clinical cases, so the disease no longer becomes public health problem. In 2014, the number of cases increased to 66 in Teluk Bintan, Teluk Sebong and Sri Kuala Lobam Subdistricts, and were comprised of 45 males and 21 females. ${ }^{7}$

The geographical condition of Bintan District constitutes of highlands, forest, plantation and swamp areas. Major occupations of the local people are farmer, plantation worker, fisherman and trader. There is a habit among the people to come and sit together in food stalls, especially during the night. ${ }^{7}$ The high of fillariasis cases and the still unknown factors related to those cases were the main reasons for this study that aimed to find out relation between environmental and behavioral risk factors with filariasis incidence in Bintan District in 2015.

\section{Method}

This study was an analytic observational using casecontrol design. Location of study was in Bintan District as conducted from May to September 2015. Study population was 66 filariasis cases taken from the data of Bintan District Health Agency in 2014. Samples were all those population, and some inclusion criteria applied were receiving health services from the government and still living in Bintan District at the time of study. However, persons who refused to be interviewed were excluded from the sample list. Based on those criteria, 33 samples of filariasis cases were selected by following cluster random sampling technique. To fulfill the case control design, a number of non-filariasis sufferers were also involved in. By using a ratio of 1:2 between the case and the control, 65 people were selected as the control group. The condition in study location made the number of control hard to reach its optimal size, for instance, there was one case that only had one neighbor.

The distance from respondents' houses to sub-variables of stockyard, swamp, bushe, seashore, plantation/forest (supportive and not supportive) were measured by using measuring-tape and stated in meter unit. The sub-variables of salinity (normal and high) and $\mathrm{pH}$ (high and low) were measured by using salinity-meter and universal indicator respectively. The sub-variables of wire-net, ceiling, and ditch/sewerage (meet and unmeet the requirements), mosquito-net (in-use and not in-use), and reservoir animals (present and not present) were observed by using check list. The sub-variables of income (high and low), gender (male and female), age (produc- 
tive and non-productive), education (high and low), occupation (employed and unemployed), knowledge (good and bad), attitude (good and bad), mosquito repellant (in-use and not in-use), clothes hanging (yes and no), night going-out (yes and no) were measured by using questionnaire.

Filariasis cases as the dependent variable were obtained from documents of Bintan District Health Agency. Meanwhile, as the controls were neighbors whose houses nearest to the cases' houses and who were not suffered from filariasis. The data were then analyzed by using chi square test and logistic regression test at confidence level of $95 \%$.

\section{Results}

Results of statistical analysis concluded that independent variables which had relation with filariasis incidence were knowledge $(\mathrm{p}$ value $=0.045$; OR: 1.365), ventilation installed with wire-net $(\mathrm{p}$ value $=0.048$; OR: 1.381 ), and distance between house and stockyard ( $\mathrm{p}$ val$\mathrm{ue}=0.018 ;$ OR: 3.500$)$, swamp (p value $=0.038 ;$ OR: $1.358)$, and plantation/forest $(\mathrm{p}$ value $=0.035 ;$ OR: 0.373 ) as well as the use of mosquito-net ( $\mathrm{p}$ value $=$ 0.036; OR: 1.417). Meanwhile, sex, age, education, oc-

Table 1. Characteristics of Individuals, Environments and Filariasis Incidence

\begin{tabular}{|c|c|c|c|c|c|c|c|c|}
\hline \multirow{3}{*}{ Variables } & \multirow{3}{*}{ Category } & \multicolumn{4}{|c|}{ Filariasis Incidence } & \multirow{3}{*}{ p Value } & \multirow{3}{*}{ OR } & \multirow{3}{*}{ 95\% CI } \\
\hline & & \multicolumn{2}{|c|}{ Yes } & \multicolumn{2}{|c|}{ No } & & & \\
\hline & & $\mathbf{N}$ & $\%$ & $\mathbf{N}$ & $\%$ & & & \\
\hline \multicolumn{9}{|c|}{ Characteristics of Individuals } \\
\hline \multirow[t]{2}{*}{ Sex } & Male & 14 & 38.9 & 22 & 61.1 & 0.405 & 1.440 & $0.609-3.405$ \\
\hline & Female & 19 & 30.6 & 43 & 69.4 & & & \\
\hline \multirow[t]{2}{*}{ Age } & Productive & 18 & 30.5 & 41 & 69.5 & 0.415 & 0.702 & $0.300-1.644$ \\
\hline & Non productive & 15 & 38.5 & 24 & 61.5 & & & \\
\hline \multirow[t]{2}{*}{ Education } & High & 4 & 22.2 & 14 & 77.8 & 0.225 & 0.502 & $0.151-1.670$ \\
\hline & Low & 29 & 36.3 & 51 & 63.8 & & & \\
\hline \multirow[t]{2}{*}{ Occupation } & Employed & 13 & 39.4 & 20 & 60.6 & 0.393 & 1.463 & $0.610-3.507$ \\
\hline & Unemployed & 20 & 30.8 & 45 & 69.2 & & & \\
\hline \multirow[t]{2}{*}{ Knowledge } & Good & 16 & 26.4 & 45 & 73.8 & $0.045^{*}$ & 1.365 & $0.979-1.903$ \\
\hline & Poor & 17 & 45.9 & 20 & 54.1 & & & \\
\hline \multirow[t]{2}{*}{ Attitude } & Good & 23 & 29.1 & 56 & 70.9 & 0.051 & 1.496 & $0.913-2.454$ \\
\hline & Bad & 10 & 52.6 & 9 & 47.4 & & & \\
\hline \multicolumn{9}{|l|}{ Environments } \\
\hline \multirow{2}{*}{ Wire-net } & Present & 3 & 15.0 & 17 & 85.0 & $0.048^{*}$ & 1.381 & $1.071-1.781$ \\
\hline & Absent & 30 & 38.5 & 48 & 61.5 & & & \\
\hline \multirow{2}{*}{ Ceiling } & Present & 7 & 43.8 & 9 & 56.3 & 0.351 & 1.675 & 0.562 \\
\hline & Absent & 26 & 31.7 & 56 & 68.3 & & & \\
\hline \multirow[t]{2}{*}{ Ditch/sewerage } & Present & 16 & 34.8 & 30 & 65.2 & 0.827 & 1.098 & 0.475 \\
\hline & Absent & 17 & 32,7 & 35 & 67.3 & & & \\
\hline \multirow[t]{2}{*}{ Stockyard } & Present & 5 & 16.7 & 25 & 83.3 & $0.018^{*}$ & 3.500 & $1.195-10.253$ \\
\hline & Absent & 28 & 41.2 & 40 & 58.7 & & & \\
\hline Swamp & Not supportive & 13 & 24.5 & 40 & 75.5 & $0.038^{*}$ & 1.358 & $1.003-1.839$ \\
\hline & Supportive & 20 & 44.4 & 25 & 55.6 & & & \\
\hline Bush & Not supportive & 8 & 47.1 & 9 & 52.9 & 0.199 & 1.991 & $0.688-5.762$ \\
\hline & Supportive & 25 & 30.9 & 56 & 69.1 & & & \\
\hline Seashore & Not Supportive & 28 & 33.3 & 56 & 66.7 & 0.861 & 0.900 & $0.276-2.940$ \\
\hline & Supportive & 5 & 35.7 & 9 & 64.3 & & & \\
\hline Plantation/forest & Not supportive & 8 & 21.1 & 30 & 78.9 & $0.035^{*}$ & 0.373 & $0.147-0.950$ \\
\hline & Supportive & 25 & 41.7 & 35 & 58.3 & & & \\
\hline Salinity & Normal & 30 & 33.3 & 60 & 66.7 & 0.811 & 0.833 & $0.187-3.723$ \\
\hline & High & 3 & 37.5 & 5 & 62.5 & & & \\
\hline Water $\mathrm{pH}$ & Low & 30 & 33.7 & 59 & 66.3 & 0.982 & 1.017 & $0.238-4.352$ \\
\hline & High & 3 & 33.3 & 6 & 66.7 & & & \\
\hline Income & High & 13 & 38.2 & 21 & 61.8 & 0.486 & 1.362 & $0.570-3.252$ \\
\hline & Low & 20 & 31.3 & 44 & 68.8 & & & \\
\hline Mosquito-net & Yes & 18 & 26.9 & 49 & 73.1 & $0.036^{*}$ & 1.417 & $0.978-2.052$ \\
\hline & No & 15 & 48.4 & 16 & 51.6 & & & \\
\hline Mosquito repellent & Yes & 29 & 36.7 & 50 & 63.3 & 0.195 & 2.175 & $0.659-7.178$ \\
\hline & No & 4 & 21.1 & 15 & 78.9 & & & \\
\hline Night going-out & Yes & 16 & 44.4 & 20 & 55.6 & 0.086 & 0.472 & $0.199-1.118$ \\
\hline & No & 17 & 27.4 & 45 & 72.6 & & & \\
\hline Clothes hanging & Yes & 15 & 33.3 & 30 & 66.7 & 0.948 & 1.029 & $0.444-2.385$ \\
\hline & No & 18 & 34.0 & 35 & 66.0 & & & \\
\hline Reservoir animals & Yes & 2 & 16.7 & 10 & 83.3 & 0.158 & 0.335 & $0.073-1.724$ \\
\hline & No & 31 & 36.0 & 55 & 64.0 & & & \\
\hline
\end{tabular}


Table 2. Relation between Characteristics of Individuals, Environments and Filariasis Incidence (Multivariate Logistic)

\begin{tabular}{|c|c|c|c|c|c|c|}
\hline \multirow{2}{*}{ Variable } & \multirow{2}{*}{ Category } & \multirow{2}{*}{ B } & \multirow{2}{*}{ p Value ${ }^{a}$} & \multirow{2}{*}{$\operatorname{Exp}(B)$} & \multicolumn{2}{|c|}{ 95\% CI $\operatorname{Exp}(B)$} \\
\hline & & & & & Lower & Upper \\
\hline \multirow[t]{2}{*}{ Characteristics of Individuals } & Education & 1.245 & 0.091 & 3.471 & 0.818 & 14.729 \\
\hline & Knowledge & 1.817 & 0.002 & 6.154 & 1.898 & 19.952 \\
\hline \multirow[t]{5}{*}{ Environments } & Wire-net & 1.345 & 0.079 & 3.837 & 0.858 & 17.166 \\
\hline & Swamp & 1.300 & 0.017 & 3.668 & 1.263 & 10.650 \\
\hline & Plantation/forest & 1.108 & 0.061 & 3.027 & 0.948 & 9.663 \\
\hline & Mosquito-net & 1.351 & 0.016 & 3.861 & 1.291 & 11.549 \\
\hline & Night going-out & 1.098 & 0.037 & 2.998 & 1.068 & 8.416 \\
\hline Constant & & -3.375 & 0.000 & 0.034 & & \\
\hline
\end{tabular}

cupation, the presence of ceiling and ditch/sewerage, the distance to bush and seashore, water $\mathrm{pH}$, income, mosquito repellent use, the habit of night going-out and outfit hanging as well as presence of reservoir animals had no significant relation with filariasis incidence (all $\mathrm{p}$ value $>0.05$ ). The complete results could be seen in Table 1.

Table 2 presented multiple logistic regression to variables with chi square test results that were eligible ( $\mathrm{p}$ value $<0.25$ ). Based on the results, the most influential variables to the incidence of filariasis in Bintan District were knowledge $(\mathrm{p}$ value $=0.002 ; \mathrm{OR}=6.154)$; netting $(\mathrm{p}$ val$\mathrm{ue}=0.016 ; \mathrm{OR}=3.861)$; and swamp $(\mathrm{p}$ value $=0.017$; $\mathrm{OR}=3.668$ ). The equation is $\mathrm{y}=-3375+1.245$ (education) +1.817 (knowledge $)+1.345$ (gauze $)+1.300$ (marshes) +1.108 (gardens / forest) +1.351 (bed nets) +1.098 (night going-out). The equation was applied to predict the probability of suffering from filariasis disease incidence.

\section{Discussion}

In general, number of respondents with good knowledge was 61 persons $(62.2 \%)$. Based on the statistical test, there was a relation between knowledge and the incidence of filariasis in Bintan District ( $p$ value $=0.045$ ), and respondents with low knowledge were 1.365 times more likely to contact with filariasis. Based on results of the interviews, on average the respondents could answer the questions about filariasis. This was because the health officers often provided information to people living in high risk areas. The presence of some people who had low knowledge was because they lived in remote areas and had low education, so this condition was potential to influence their knowledge and understanding. Therefore, information sharing has to be raised continuously, but accompaniment by optimalizing roles of health cadres among the community has to be implemented as well.

Results of this study was in line with Agustiantiningsih's, ${ }^{8}$ study which stated that a relation was found between knowledge and preventive measures of filariasis ( $p$ value $<0.001$ ). Preventive efforts could be applied by doing applicative yet simple elucidation activities which comprise of advices for avoiding contact with filariasis mosquito vectors by means of using mosquitonet, closing house ventilation with wire-net, and applying mosquito repellent. ${ }^{9}$ A study conducted by Uloli, ${ }^{10}$ in Boneraya Subdistrict of Bone Bolango District obtained result that education and filariasis incidence was related ( $\mathrm{p}$ value $=0.042 ; \mathrm{OR}=2.004)$. However, different result was found in study of Ambar, et al, ${ }^{11}$ in Pangku Tolole Village that knowledge of filariasis $(p$ value $=0.431$ ) and the prevention of filariasis ( $p$ value $=0.159$ ) had no relation.

Theoretically, variation of specific elucidation method for filariasis sufferers and people living around and near to them is needed to be implemented. It can be done, for example, through video screening in coffee shops, before and after community activities, and information propagation through radio stations that is designed specifically to be inserted in favorite programs for general people, such as musical or news ones. This motivating effort hopefully can reach communities in the remote areas about the information of filariasis impact that is not immediately treated, and therefore either the surroundings people or neighbors or family members with filariasis clinical symptoms cases can be directly active bringing them to the nearest community health center. ${ }^{12}$

Good knowledge is hopefully to build good attitude, so that individuals or the community are able to solve health problems they face. People who still maintain bad attitude to filariasis may be caused by the lack of knowledge and education level they attain. It may be caused as well through less appropriate socialization activities about the disease and its corresponding preventive measures which is performed by health officers. ${ }^{13,14}$ This is because the foundation of attitude consolidation is positive behaviors of which the trust and believe about the gained advantages grow from. ${ }^{15}$

The proportion of those whose houses were far from swamps (not supportive) was $54.1 \%$ or 53 persons. The 
statistical test showed that swamp was significantly related to filariasis incidence $(\mathrm{p}$ value $=0.038)$, and the risk of getting filariasis was 1.358 times higher. A study by Uloli, ${ }^{10}$ stated that living near swamp environment was correlated with filariasis incidence ( $\mathrm{p}$ value $=0.017$; OR: 3.563). Study conducted by Jontari, 16 also concluded that there was a relation between human settlement and swamp in the surrounding $(<500$ meter $)$ and the filariasis incidence $(\mathrm{p}$ value $=0.008)$. These conditions depicted that transmission of filariasis was so influenced by interaction between human behavior and the surrounding environment which had possibility to support filariasis infection. ${ }^{17}$ Wire-net installed at house ventilation aimes to reduce the frequency of mosquito bite, therefore will prevent the potential risk of contracting filariasis. ${ }^{18}$ Ministry of Health states that habit of using wire-net for mosquito protection is highly needed, especially for people living in endemic areas or near swamps, plantations and rice fields where mosquito bite is very intense. ${ }^{19}$

A study conducted by Sipayung, et al, 20 concluded that existence of biological environment around houses is related to lymphatic filariasis incidence in the endemic areas of Sarmi District ( $\mathrm{p}$ value $=0.005)$. Upadhyayula's, ${ }^{21}$ study in India found relation between presence of mosquito's breeding places and filariasis incidence $(\mathrm{p}$ value $=0.002)$. Meanwhile, Ike's, ${ }^{22}$ study found that in Pekalongan District, relation between biological environment and filariasis incidence was identified. Lasbudi's, ${ }^{23}$ study stated that mosquito density was found more in place that has suitable temperature, humidity and illumination for mosquito's growth and development, so potential for filariasis incidence.

The existence of water puddle will increase the risk of being infected by filariasis because this condition can increase mosquito population. The Ministry of Health says that endemic location for Brugia malayi is areas with forest and swamps along river flow, or water body that full with water plants. ${ }^{2}$ A study conducted by Ashari, 24 found relation between presence of water plants and filariasis incidence. The study also found that people living in houses with mosquito habitat were eight times more likely to get filariasis. In addition, a study of Mulyono, et $a l,{ }^{25}$ concluded that water puddle was the risk factor of filariasis 4.14 times higher.

Therefore, swamp is highly related to bionomics of mosquito vectors since this type of environment is used as both breeding and resting places for the insects. Water plants are breeding places for Mansonia mosquitoes as the larva's and the pupas of this species breathing by means of the plants' roots beneath the water surface, and through the floating stalks and leaves. ${ }^{26}$

The need of high humidity level affects mosquitoes to seek damp and wet places outside people's houses as their resting place during day time. Anopheles farauti, one of filariasis vectors, enters houses just for blood sucking and afterward go out of the houses to perch for maturing their eggs. One of the preferred outdoor places is shady spots with trees. ${ }^{27}$

Management of the environment is very important for controlling the vector mosquitoes of diseases. Immediate intervention is needed to lessen the swamps, to treat the unoccupied yards, and to install mosquito traps, so that can force the vector control to run more optimal. ${ }^{2}$ The government hopefully can do communication with plantation companies about reinvestment and Corporate Social Responsibility (CSR), such as development of healthy houses, the control and size reduction of swamps, and the management of unoccupied yards as breeding places for mosquitoes in order to diminish the biting intensity of filariasis-causing mosquitoes.

Based on the interviews and observations which has been carried out, the proportion of those using mosquito-net was $68.4 \%$ or 67 people. Test of relation showed that habit of not using mosquito-net had significant relation to filariasis incidence ( $\mathrm{p}$ value $=0.036)$, and risk of contracting filariasis was 1.417 times higher.

Results of Jontari's study concluded that sleeping without using mosquito-net $(\mathrm{p}$ value $=0.029$; $\mathrm{OR}=$ 1.170) was the risk factor of filariasis. ${ }^{16}$ A study conducted by Ambar, ${ }^{11}$ identified relation between prevention and self-protection methods by using mosquito-net or repellent, and filariasis incidence ( $\mathrm{p}$ value $=0.038$ ). It was identified as well that $61.25 \%$ of respondents owned mosquito-net and used it. Results of study conducted by Juriastuti, 28 is different that found no relation between the use of mosquito-net and filariasis incidence. The main effort of filariasis prevention is keep away from the biting of mosquito vectors, such as by using mosquito-net when sleeping, covering house ventilation with wire-net, and rubbing skins with mosquito repellent. ${ }^{3}$

Based on the results of multiple logistic regression test, four variables showed significant relation to filariasis incidence, such as knowledge, mosquito-net use, swamp, and night going-out. Similar results were also obtained by Febrianto's, ${ }^{18}$ study which concluded that the dominant factors for filariasis incidence were mosquitonet and ceiling construction. Meanwhile, a study of Nasrin, ${ }^{12}$ found that the most dominant risk factors of filariasis incidence in West Bangka were occupation, income, swamp presence, and respondents' knowledge level.

Main focus for Filariasis handling in Bintan District starts from knowledge increasing efforts by means of health promotion activities equipped with elucidation and information dissemination through pictorial banners, as well as by socialization about the importance of mosquito-net use as preventive measure from mosquito bites, and the distribution of the nets to people, especially those 
living in case areas. Prevention action for filariasis can be carried out by cleaning breeding places of the mosquitoes, burying used stuffs potential for becoming water containers, draining water containers, mass insecticide spraying, wearing self-protective devices when working at plantation, such as long sleeve apparel, applying mosquito repellent on skin, using mosquito-net when sleeping, not going-out home at night, and covering ventilation with wire-net. ${ }^{29,30}$ These actions should be integrated held through coordination with all stakeholders among the community, private sectors and the government (cross program and cross sector). Community empowerment is also needed for up-leveling the behaviors of clean and healthy living. ${ }^{31,32}$ At the end, all those activities can contribute to the success of filariasis eliminating program that has been declared by the local government of Bintan District.

\section{Conclusion}

There is no relation found between sex, age, occupation, education, attitude, ceiling, ditch/sewerage, salinity, water $\mathrm{pH}$, bush, seashore, income, mosquito repellent, night going-out, clothes hanging and reservoir animals, and the incidence of filariasis in Bintan District. On the other hand, knowledge, wire-net use, stockyard, swamp, plantation/forest, and mosquito- net are related to the incidence of the disease. Factors most related to filariasis incidence in Bintan District are knowledge, mosquito-net use and swamp.

\section{Recommendation}

The community health centers should keep strengthening the surveillance system, especially for the subsidiary health centers throughout and in remote areas of Bintan District. Then people should use mosquito-net or repellent when sleeping or going out at night. Vectors and environment (swamp and plantation/forest) control should be implemented in an integrated manner by strengthening cross-sectoral coordination including the mining companies and plantations around filariasis-endemic areas.

\section{References}

1. World Health Organization. Monitoring and epidemiological assessment of the program to eliminate lymphatic filariasis at implementation unit level. Geneva: World Health Organization; 2005.

2. Departemen Kesehatan Republik Indonesia. Pedoman penentuan daerah endemis penyakit kaki gajah. Jakarta: Direktorat Jenderal Pemberantasan Penyakit Menular \& Penyehatan Lingkungan Departemen Kesehatan Republik Indonesia; 2004.

3. Departemen Kesehatan Republik Indonesia. Mengenal filariasis (penyakit kaki gajah). Jakarta: Direktorat Pengendalian Penyakit Bersumber Binatang Departemen Kesehatan Republik Indonesia; 2009.

4. Ramadhani T. Filariasis limfatik di Kelurahan Pabean Kota Pekalongan.
Kesmas: Jurnal Kesehatan Masyarakat Nasional. 2008; 3 (2): 51 - 6.

5. Departemen Kesehatan Republik Indonesia. Pedoman pengobatan massal penyakit kaki gajah. Jakarta: Direktorat Jenderal Pemberantasan Penyakit Menular \& Penyehatan Lingkungan; 2002.

6. Srividya A, Michael E, Palaniyandi M, Pani SP, Das PK. A geostatistical analysis of ymphatic Filariasis prevalence in Southern India. American Journal of Tropical Medicine \& Hygiene. 2002; 67 (5): 480 - 9.

7. Dinas Kesehatan Kabupaten Bintan. Profil dinas kesehatan Kabupaten Bintan 2013. Bintan: Dinas Kesehatan Kabupaten Bintan; 2013.

8. Agustiantiningsih D. Praktik pencegahan filariasis. Jurnal Kesehatan Masyarakat Unnes. 2013; 8 (2): 190 - 7.

9. Syuhada Y, Nurjazul, Wahyuningsih NE. Studi lingkungan rumah dan perilaku masyarakat sebagai faktor risiko kejadian filariasis di Kecamatan Buaran dan Tirto Kabupaten Pekalongan. Jurnal Kesehatan Lingkungan Indonesia. 2012; 11 (1): 95 - 101.

10. Uloli R. Faktor-faktor risiko kejadian filariasis di Kabupaten Bone Bolango, Propinsi Gorontalo [magister thesis]. Yogyakarta: Universitas Gadjah Mada; 2007.

11. Ambar TG, Jastal, Rosmini, Hayani A, Yuyun S, Yudith L. Filariasis dan beberapa faktor yang berhubungan dengan penularannya di Desa Pangku-Tolole, Kecamatan Ampibabo, Kabupaten Parigi-Moutong, Provinsi Sulawesi Tengah. Jurnal Vektora. 2013; 5 (2): 54 - 65.

12. Nasrin. Faktor lingkungan dan perilaku yang berkaitan dengan kejadian filariasis di Kabupaten Bangka Barat [magister thesis]. Semarang: Universitas Diponegoro; 2008.

13. Graham, Andrea L. Malaria-filaria coinfection in mice malarial desease more severe unless filarial infection achieves. Infectious Disease. 2015; 191 (3): 410-21.

14. Sabesan S, Raju Hk, Srividya A, Das PK. Delimitation of lymphatic filariasis transmission risk areas: ageo-environmental approach. Filaria Journal. 2006; 5 (12): 1-6.

15. Made AN. Aspek epidemiologis dalam penanggulangan filariasis di Indonesia. Jurnal Vektor Penyakit. 2009, 3 (1): 33-40.

16. Jontari, Hari K, Supargiyono, Hamim S, Faktor-faktor risiko kejadian penyakit lymphatic filariasis di Kabupaten Agam, Propinsi Sumatera Barat Tahun 2010. Outbreak, surveillance and investigation report [ serial on internet]. March 2014 [cited 2015 Nov 5]; 7 (1): 9-15. Available form http://www.osirjournal.net /upload/files /2_\%20LF20 (Indonesia) .pdf

17. Ardias, Setiani, Hanani. Faktor lingkungan dan perilaku masyarakat yang berhubungan dengan kejadian filariasis di Kabupaten Sambas. Jurnal Kesehatan Lingkungan. 2012; 11(2): 199 - 207.

18. Febrianto B, Astri M, Maharani, Widiarti, Faktor risiko filariasis di Desa Samborejo, Kecamatan Tirno, Kabupaten Pekalongan Jawa Tegah [online]. Available from: http://litbangdepkes.go.id/-djunaedi/documentation/360208pdf/bagus.pdf

19. Departemen Kesehatan Republik Indonesia. Pedoman program eliminasi penyakit kaki gajah. Jakarta: Direktorat Jenderal Pemberantasan Penyakit Menular \& Penyehatan Lingkungan Departemen Kesehatan Republik Indonesia; 2005.

20. Sipayung M, Wahjuni CU, Devy SR. Pengaruh lingkungan biologi dan upaya pelayanan kesehatan terhadap kejadian filariasis limfatik di Kabupaten Sarmi. Jurnal Berkala Epidemiologi. Mei 2014; 2 (2): 26373. 
21. Upadhyayula SM, Mutheneni SR, Kadiri MR, Kumaraswamay S, Nagalla B. A cohort study of lymphatic filariasis on socio economic conditions in Andhra Pradesh, India. PloS one. 2012; 7(3): e33779.

22. Windiastuti IA, Suhartono, Nur, Suhartono, Nurjazuli. Hubungan kondisi lingkungan, sosial ekonomi dan perilaku masyarakat dengan kejadian filariasis di Kecamatan Pekalongan. Jurnal Kesehatan Lingkungan Indonesia. April 2013; 12 (1): 51 - 7.

23. Lasbudi P. Studi komunitas nyamuk di Desa Sebubus (daerah epidemis filariasis) Sumatera Selatan tahun 2004. Jurnal Ekologi Kesehatan. April 2006; 5(1): 368 - 75 .

24. Anshari, R. Analisis faktor risiko kejadian filariasis di Dusun Tanjung Bayur Desa Sungai Asam Kecamatan Sungai Raya Kabupaten Pontianak [thesis]. Semarang: Universitas Diponegoro; 2014.

25. Mulyono RA. Risk factor environmental and behaviour influence the occurance of filariasis (case study in area Pekalongan). Jurnal Bina Sanitasi. Desember 2008; 1 (1): 18 - 27.

26. Suwasno H. Peranan tumbuhan air sebagai pengurang pencemaran dan tumbuhan inang vektor filariasis Mansonia $s p$. Media penelitian dan pengembangan kesehatan. 2008; 36 (2): 48 - 58.
27. Pranoto AM. Beberapa aspek perilaku An. farauti di Klademak IIA. Cermin dunia kedokteran. 1995; 10 (1): 199 - 204.

28. Juriastuti P, Kartika M, Djaja IM, Susanna D. Faktor risiko kejadian filariasis di Kelurahan Jati Sempurna. Makara Seri Kesehatan. Juni 2010; 14 (1): 31-6.

29. Agrawal Lt Col Vk, Shasindran Wg Cdr VK. Lymphatic filariasis in India: problems, challenges and new initiatives. Medical Journal Armed Force India. 2006; 62 (4): 359 - 62.

30. Burton GJ. Attack on the vector on filariasis in British Guiana. Public Health Report (1896-1970) [online]. Februari 1964 [cited 2015 Jan 5]; 79 (2). Available from: http://www.jstor.org/ stable /4592075.

31. Rath K, Nath N, Mishra S, Swain K, Mishra S, Babu V. Knowledge and perceptions about lympahatic filariasis: about lymphatic filariasis: a study during the programme to eliminate lymphatic filariasis in an urban community of Orissa, India. Tropical Biomedicine. 2006; 23: 156 - 62.

32. David GA, Molly AB. Morbidity management in global programme to eliminate lymphatic Filariasis : a review of scientific literature. Filaria Journal. 2007; 6 (2): 1 - 19 